\title{
RFamide peptides, the novel regulators of mammalian HPG axis: A review
}

\author{
Smruti Smita Mohapatra (iD), Joydip Mukherjee (i), Dipak Banerjee (D), Pradip Kumar Das(D), Prabal Ranjan Ghosh and \\ Kinsuk Das (i)
}

\begin{abstract}
Department of Veterinary Physiology, Faculty of Veterinary and Animal Sciences, West Bengal University of Animal and Fishery Sciences, Kolkata, West Bengal, India.

Corresponding author: Joydip Mukherjee, e-mail: joyphy@gmail.com

Co-authors: SSM: simplysmruti@gmail.com, DB: dipakndri@gmail.com,PKD: pkdaskol@rediffmail.com, PRG: drprghosh@gmail.com, KD: kin.suk@hotmail.com

Received: 10-03-2021, Accepted: 10-06-2021, Published online: 20-07-2021
\end{abstract}

doi: www.doi.org/10.14202/vetworld.2021.1867-1873 How to cite this article: Mohapatra SS, Mukherjee J, Banerjee D, Das PK, Ghosh PR, Das K (2021) RFamide peptides, the novel regulators of mammalian HPG axis: A review, Veterinary World, 14(7): 1867-1873.

\begin{abstract}
The RFamide-related peptides (RFRPs) are the group of neuropeptides synthesized predominantly from the hypothalamus that negatively affects the hypothalamo-hypophyseal-gonadal (hypothalamic-pituitary-gonadal [HPG]) axis. These peptides are first identified in quail brains and emerged as the mammalian orthologs of avian gonadotropin inhibitory hormones. The RFRP-3 neurons in the hypothalamus are present in several mammalian species. The action of RFRP-3 is mediated through a G-protein-coupled receptor called OT7T022. The predominant role of RFRP-3 is the inhibition of HPG axis with several other effects such as the regulation of metabolic activity, stress regulation, controlling of non-sexual motivated behavior, and sexual photoperiodicity in concert with other neuropeptides such as kisspeptin, neuropeptide-Y (NPY), pro-opiomelanocortin, orexin, and melanin. RFamide peptides synthesized in the granulosa cells, interstitial cells, and seminiferous tubule regulate steroidogenesis and gametogenesis in the gonads. The present review is intended to provide the recent findings that explore the role of RFRP-3 in regulating HPG axis and its potential applications in the synchronization of reproduction and its therapeutic interventions to prevent stress-induced amenorrhea.
\end{abstract}

Keywords: hypothalamic-pituitary-gonadal axis, reproduction, RFamide-related peptides-3.

\section{Introduction}

The hypothalamic-pituitary-gonadal (HPG) axis or gonadotropic axis consisting of the hypothalamus, pituitary gland, and gonads is the key regulator of reproduction in mammals. It operates through coordinated mechanisms of hypothalamic gonadotropin-releasing hormone $(\mathrm{GnRH})$ and hypophyseal gonadotropins (follicle-stimulating hormone [FSH] and Luteinizing hormone $[\mathrm{LH}]$ ) with peripherally produced gonadal hormones [1]. GnRH, the key operator secreted in two modes from the gonadotropic axis - pulsatile and surge [2]. GnRH pulse generator at the mediobasal hypothalamic area controls the pulsatile release of GnRH [3]. Pre-optic area $\mathrm{GnRH}$ surge generator is responsible for pre-ovulatory LH surge [4]. Hypothalamus receives feedback signals from gonads through gonadal hormones. Estradiol exerts both negative and positive feedback in a dose-dependent manner during different reproductive cycle stages in females [5] in contrast to testosterone which has only negative feedback over the GnRH release. However, surprisingly, GnRH neurons lack estradiol receptor (ER) and deletion of GnRH-specific ER $\beta$ has

Copyright: Mohapatra, et al. Open Access. This article is distributed under the terms of the Creative Commons Attribution 4.0 International License (http://creativecommons.org/licenses/ by/4.0/), which permits unrestricted use, distribution, and reproduction in any medium, provided you give appropriate credit to the original author(s) and the source, provide a link to the Creative Commons license, and indicate if changes were made. The Creative Commons Public Domain Dedication waiver (http:// creativecommons.org/publicdomain/zero/1.0/) applies to the data made available in this article, unless otherwise stated. no effect on the reproductive cycle in mice [6]. These observations have led researchers across the globe to find out the mechanism behind the control of HPG axis and several neuropeptides controlling GnRH release. Kisspeptin neurons [7] and RFamide-related peptides (RFRP)-3 neurons [8] have emerged as the key neuropeptides having a stimulatory and inhibitory effect on GnRH secretion, respectively. The kisspeptin neurons located in the pre-optic area and median eminence regulates both GnRH surge and pulsatile center, respectively. Kisspeptin-induced GnRH secretion is well documented in rat [9], mouse [10], sheep [11], cow [12], rhesus macaque [13], and human [14]. Kisspeptin induces the positive feedback of sex steroids on HPG axis in rodents [15]. The role of kisspeptin on metabolic regulation of reproductive cyclicity through leptin is also reported [16]. However, compared to kisspeptin, much less attentions have been paid to inhibitory neuropeptides and RFamide-related peptides which emerged as the promising areas of research in reproductive endocrinology in mammals.

\section{Discovery of Gonadotropin Inhibitory Hormones (GnIH)/RFRPs}

Tsutsui et al. [17] identified a group of neuropeptides that inhibit pituitary gonadotropin in vitro pituitary cell culture of adult male quail. It was named GnIH due to its selective inhibitory property over gonadotropins. The receptors of the GnIH have also been identified in the pituitary of quails and in vivo experiments confirm 
that $\mathrm{GnIH}$ administration inhibits the expression of $\alpha$ and $\beta$ subunits of FSH and LH [18]. The sequencing of $\mathrm{GnIH}$ revealed Ser-Ile-Lys-Pro-Ser-Ala-Tyr-LeuPro-Leu-Arg-Phe-NH2 sequence and due C-terminal LPXRFamide sequence $(\mathrm{X}=\mathrm{L}$ or $\mathrm{Q})$, so termed as LPXRFamide peptides. The five classes RFamide peptides in mammals are $\mathrm{GnIH}$, neuropeptide FF (NPFF), prolactin-releasing peptide, kisspeptin (kiss1 and kiss2), and pyroglutamylated RFamide peptide/26RFamide peptide (QRFP/26RFa). RFRP-1, -2, and -3 in mammals are orthologous to avian $\mathrm{GnIH}$ [19], of which RFRP-3 is considered as the true homolog of $\mathrm{GnIH}$ concerning gonadotropin secretion in mammals [20]. The RFRP-1, -2 , and -3 are encoded by NPVF gene in humans [21]. Of the three RFamide-related peptides, RFRP-1 and RFRP-3 are reported to be functionally active [21]. RFRP-1 and RFRP-3 have been isolated from cattle [12], human [22], and Siberian hamster [23].

\section{Localization of RFRP-3 Neurons in the Hypothalamus}

There are huge variations among species regarding the localization of RFRP-3 neurons in the brain. The sexual variations in the localization patterns are also found in different species. Table-1 summarizes the localizations of RFRP-3 in different parts of the hypothalamus [23-37].

\section{RFRP-3 Receptors}

Nguyen et al. [38] identified two receptors for NPFF - NPFF1R and NPFF2R under the G protein-coupled receptor (GPCR) family. Hinuma et al. [21] reported a specific RFRP receptor called OT7T022 which showed binding capabilities against synthetic
hRFRP-1 and hRFRP-3 ligands. HLWAR77 receptor reported by Elshourbagy et al. [39] showed specificity for both neuropeptides AF and NPFF. The functional identity between OT7T022, NPFF1R, and a GPCR (GPR147) has been reported. HLWAR77 and NPFF2R have functional similarities with GPR74. GPR147/NPFFR1 is the receptor for GnIH/RFRP-3. GPR147 is reported to be coupled with $\mathrm{G}_{\mathrm{i}}^{\alpha}$, an inhibitory $\mathrm{G}$ protein that suppresses cAMP activity [21]. Gouardères et al. [40] reported that GPR147 can bind $\mathrm{G}^{\alpha}{ }_{\mathrm{s}}$ or $\mathrm{G}^{\alpha}{ }_{\mathrm{q}}$ proteins which explain the diverse role of RFRP-3. GPR147 has been identified in hypothalamus, pituitary, gonads, and accessory reproductive organs in birds [41]. Extra neural localization of RFRP-3 has been reported in male and female gonads of mice, Syrian hamsters, and rhesus macaques [42]. In testes, the predominant sites of GPR147 expression are spermatocytes and spermatids [43]. GPR147 has been identified in granulosa cells, theca cells, and luteal cells depending on the stages of the reproductive cycle [43].

\section{Functions of RFRP-3 in Reproduction}

\section{Regulation of GnRH secretion}

RFRP-3 inhibits GnRH synthesis and secretion from the hypothalamus directly or indirectly in mammals. The RFRP-3 secreting neurons are situated in close apposition with RnRH secreting neurons along with substantial evidence of GPR147 expression in GnRH secreting cells and their projections. Intercerebroventricular (ICV) injection of RFRP-3 suppresses GnRH neuronal activity in female rats and mice [44]. In vitro cell culture studies confirmed the suppression of GnRH neuronal firing rates [19]. The indirect effect of RFRP-3 on GnRH neurons is

Table-1: Localization of RFRP-3 neurons and its projections in the hypothalamus in different species.

\begin{tabular}{|c|c|c|c|}
\hline Species & Localization of RFRP-3 neurons & $\begin{array}{l}\text { Neuronal projections of RFRP-3 } \\
\text { neurons }\end{array}$ & Reference \\
\hline Human & DMN & Infundibulum, ME and POA & [24] \\
\hline Sheep & DMN and PVN & $\begin{array}{l}\text { Arcuate nucleus (ARC), PVN, ventromedial } \\
\text { hypothalamic nucleus, DMN, and lateral } \\
\text { hypothalamic area }\end{array}$ & {$[25-27]$} \\
\hline Mice & $\begin{array}{l}\text { DMN, the solitary tract nucleus, and } \\
\text { lateral superior olive }\end{array}$ & $\begin{array}{l}\text { Reticular nucleus, spinal trigeminal } \\
\text { nucleus, parabrachial nucleus, up to the } \\
\text { dorsal horn of the spinal cord except ME }\end{array}$ & {$[28]$} \\
\hline Siberian hamster (male) & $\begin{array}{l}\text { AH area, pre-mammillary nucleus, } \\
\text { and DMN }\end{array}$ & $\begin{array}{l}\text { Arcuate nucleus central gray, amygdala, } \\
\text { lateral septal nucleus, medial POA }\end{array}$ & [23] \\
\hline Siberian hamster (female) & DMN & $\mathrm{ME}$ & [29] \\
\hline Rhesus macaque (male) & Intermediate periventricular nucleus & $\begin{array}{l}\text { PVN, POA, IPe, ME, ARC, and dorsal } \\
\text { hypothalamic area }\end{array}$ & [24] \\
\hline Rhesus macaque (female) & $\begin{array}{l}\text { Intermediate periventricular nucleus } \\
\text { together with PVN and DMN }\end{array}$ & POA and medial basal hypothalamus & {$[30]$} \\
\hline Rats (either sex) & DMN, ARC, lateral hypothalamic area & $\begin{array}{l}\text { Hippocampus, PVN, POA, AH, lateral } \\
\text { hypothalamus }\end{array}$ & {$[31-33]$} \\
\hline Rats (male) & $\begin{array}{l}\text { DMN, dorsal tuberomammillary } \\
\text { nucleus, } \mathrm{DMH} \text {, and } \mathrm{VMH}\end{array}$ & Amygdala, diencephalon, MPOA, PVN & [34] \\
\hline Naked mole-rats & $\mathrm{DMH}, \mathrm{ARC}$ & MPOA, SEP, PVN, Arc, and ME & {$[35]$} \\
\hline Pigs & PVN, DMN & Lateral hypothalamus & [36] \\
\hline Mare & PVN, DMN & ----- & [37] \\
\hline \multicolumn{4}{|c|}{$\begin{array}{l}\text { RFRP=RFamide-related peptides, } \mathrm{POA}=\text { Pre-optic area, } \mathrm{MPOA}=\text { Medial pre-optic area, } \mathrm{DMN}=\text { Dorsomedial nucleus, } \\
\mathrm{PVN}=\text { Paraventricular nucleus, } \mathrm{ME}=\mathrm{Median} \text { eminence, } \mathrm{ARC}=\text { Arcuate nucleus, } \mathrm{AH}=\text { Anterior hypothalamic, } \\
\mathrm{DMH}=\text { Dorsomedial hypothalamus, } \mathrm{VMH}=\text { Ventromedial hypothalamus }\end{array}$} \\
\hline
\end{tabular}


mediated through kisspeptin. In mice, around 9-16\% of kisspeptin neurons in the AVPV/RP3V area and $25 \%$ of kisspeptin neurons in the ARC area express GPR147 and 19-35\% of kisspeptin neuron projections [45]. Decreased expression of kisspeptin mRNA in the hypothalamus upon intracerebroventricular administration of RFRP-3 has been reported in rats [44] and mice [46]. Wu et al. [47] reported that RFRP-3 could block glutamate transporter 2 in the GnRH neurons induced by kisspeptin.

\section{Regulation of LH secretion}

Controversial results on the effect of RFRP-3 on pituitary LH secretion have been documented in different animal models. RFRP-3 decreases LH secretion in gonadectomized male and female rats intravenously [48]. Rizwan et al. [31] reported no change in the LH secretion on IV administration in ovariectomized rats. Acute RFRP-3 administration through ICV route reports no change in LH secretion in both gonadectomized male and female rats [48]. Chronic ICV injections of RFRP-3 cause a non-significant decrease in LH secretion and pulsatility in adult ovariectomized rats [49]. Administration of RFRP-3 through the intraperitoneal route has no effect on LH secretion in adult male or female mice [20]. Ubuka et al. [23] and Henningsen et al. [50] reported decreased LH secretion on acute ICV administration of RFRP-3, but it caused increased LH secretion in males under both long-day and short-day photoperiod. Decreased LH pulse has been reported upon IV administration of RFRP-3 in both intact and ovariectomized sheep [27], but no change in LH concentration is also reported [51]. No changes in the LH pulse secretion and amplitude on intravenous RFRP-3 administration were reported in mare [37] and gilt [36]. Intravenous administration of RFRP-3 in postmenopausal women causes decreased LH secretion [52]. Kadokawa et al. [12] reported decreased LH pulse frequency without altering the mean LH concentration on IV administration of RFRP-3 in male cattle. Blocking LH secretion by RFRP-3 can be mediated by three routes such as RFRP-3-kisspeptin-GnRH-LH, RFRP-3-GnRH-LH, and RFRP-3-LH as per the collective evidence.

\section{Effect of RFRP-3 on gonads}

The paracrine action of RFRP-3 on the gonads is established. Bentley et al. [41] reported that $\mathrm{GnIH}$ is synthesized in the granulosa cells, interstitial cells, and seminiferous tubules in birds. McGuire et al. [53] reported inhibition of testosterone synthesis by $\mathrm{GnIH}$ in avian testicular cell culture. Species such as rats [54], mice [55], Syrian hamsters [56], sheep [57], pigs [58], primates [59], and human [55] are able to synthesize RFRP-3 in their gonads. The GPR 174 receptors of RFRP-3 have been identified in the oviduct, epididymis, and vas deferens of birds [41]. The localization of GPR-174 has been reported in the granulosa cell layer of pre-ovulatory follicles and corpus luteum in premenopausal women in which RFRP-3 inhibits gonadotropin-induced progesterone synthesis [55]. Singh et al. [42] identified RFRP-3 receptors in the granulosa cells of both healthy antral follicles during proestrus and estrus and in luteal cells during diestrus in mice establishing the role of RFRP-3 in follicular development. Zhao et al. [56] identified RFRP-3 and its receptors in spermatocytes and spermatids by immunohistochemistry and in situ hybridization and reported increased expression of RFRP-3 and GPR147 during late spermatocytes indicating the role of RFRP-3 in sperm maturation. Anjum et al. [60] studied the expression of $\mathrm{GnIH}$ in the testis of mice and correlated with serum testosterone levels from birth to senescence and found that RFRP-3 may cause pubertal activation of senescence in mice testis.

\section{Effect of RFRP-3 on sexual photoperiodism}

A photoneuroendocrine system regulates sexual photoperiodism in mammals comprised of the photoreceptors in the retina, hypothalamus (suprachiasmatic nucleus), and the pineal gland. The pineal hormone melatonin released on photoperiodic cues is the key communicator between reproductive activity and seasons [61]. Higher melatonin production occurs at night; thus, nocturnal melatonin production is higher in seasons with short-day length (autumn/winter) than spring/summer [62]. The mechanism behind melatonin-induced sexual photoperiodism is not well. However, studies have shown that melatonin modulates some gene expressions in brain loci [63]. $\mathrm{GnIH}$ expression and release are directly regulated by melatonin acting on Mel1c receptors specifically expressed in $\mathrm{GnIH}$ neurons of quails [64]. In contrast to mammalian seasonal species, $\mathrm{GnIH}$ expression is increased by melatonin, and consequently, GnIH-ir expression is increased in short photoperiod as to long photoperiod [64]. In vitro studies show that GnIH release has a diurnal rhythm and is increased during nighttime in quail hypothalamic explants [65]. Bentley et al. [41] studied that elimination of pineal gland and reduced melatonin secretion markedly decreased GnIH expression in photoperiodic quail and song sparrows. This can be revived after the replacement of melatonin [64].

\section{Role of RFRP-3 on pre-ovulatory LH surge}

Vasoactive intestinal peptide (VIP) and arginine vasopressin (AVP) are the two important neurotransmitters of the suprachiasmatic nucleus (SCN), which controls the daily rhythms GnRH secretion and the timing of the pre-ovulatory LH surge [5]. Russo et al. [66] reported that AVP and VIP releasing nerve fibers were in close apposition with RFRP-3 and around 10\% RFRP-3 neurons expressed VPAC1 and VPAC2 receptors. He demonstrated that injection of VIP decreased RFRP-3 activity in the afternoon, not in the morning hence in a time-dependent manner. Lower expression of RFRP-3 coincides with LH surge in mice [45] and Syrian hamsters [50]. Simonneaux et al. [67] proposed a model on the role of RFRP-3 on pre-ovulatory LH surge where he stated 
that AVP and VIPergic neurons of SCN were the main regulators of the internal circadian clock in response to light output. SCN-VIP route controls GnRH neuronal activity either directly or through RFRP-3 neurons at DMH, whereas the SCN-AVP route stimulates GnRH activity through kisspeptin receive positive feedback from estradiol. These coordinated mechanisms are responsible for timely LH surges under the dark and light cycle.

\section{Effect of RFRP-3 on sexual maturation}

RFRP-3 inhibits gonadotropin secretion in pre-pubertal animals. Sun et al. [68] demonstrated that the expression RFRP3/GPR147 mRNA in the hypothalamus is gradually decreased with puberty onset in rats. Xiang et al. [46] reported that RFRP-3 inhibits LH in estradiol dependent manner in pre-pubertal mice, not in adults. The differential expression of RFRP-3 neurons in the nucleus accumbens shells that regulates sexual motivation between sexually quiescent and active rats highlights the role of RFRP-3 on sexual maturity [35]. Han et al. [44] demonstrated that ICV injection of RFRP-3 delays puberty onset in female rats. Thorson et al. [36] reported the suppression of LH in ovariectomized prepubertal gilts by RFRP-3. These findings suggest the role of RFRP-3 to suppress HPG axis before puberty. Johnson and Fraley [69] reported that there are no alterations in the pubertal onset in RFRP-3 and GPR 147 knocked down models. Lima et al. [70] reported that RFRP-3 and GPR147 gene variants are not associated with GnRH-dependent pubertal disorders.

\section{Role of RFRP-3 in stress-induced reproductive suppression}

Stress is reported to inhibit HPG axis and hence the reproductive function. The role of $\mathrm{GnIH}$ on stress-induced reproductive suppression was first reported by Calisi et al. in house sparrows [71]. RFRP-3 causes stress in chicken [65], zebra finches [72], mice [73], and rats [74]. Acute immobilization stress in mice causes a rapid increase in RFRP-3 gene expression and protein level coincides with higher glucocorticoid secretion [75]. Kaewwongse et al. [74] reported similar findings in rats on foot shock stress. McGuire et al. [76] reported that metabolic stress increased $\mathrm{GnIH}$ expression in ovaries of songbirds. Jaroslawska et al. [73] reported decreased RFRP-3 expression on the cold temperature in mice. The expression of glucocorticoid receptors in GnIH neurons in quails and corticosterone administration inhibits GnIH mRNA expression in quails [77]. Corticosterone induces upregulation of RFRP-3 in the testis of European starlings [36]. Direct action of glucocorticoids on RFRP-3 secreting neurons was established in rat hypothalamic cell culture [77]. The molecular mechanism of glucocorticoid-mediated RFRP-3 activations is confirmed after identifying glucocorticoid response elements in the RFRP-3 precursor coding region [78].
Stress-induced infertility is reported to be reversed after silencing of RFRP-3 in female rats [79].

\section{Role of RFRP-3 on feeding behavior and energetics}

Optimum energy status is an essential factor for reproduction. Neurochemical systems regulate it. RFRP-3 increases feed intake in rodents [48], sheep [80], and primates [81]. The localization of RFRP-3 neurons in the DMH and PVN plays an important role in energy balance as these areas of the hypothalamus play a significant role in feeding [82]. Qi et al. [25] reported that RFRP-3 neurons are projected to NPY, pro-opiomelanocortin (POMC), orexin, and melanin-concentrating cells, key regulators of feeding, and energy status of animals. Administration of RFRP-3 through ICV route is reported to stimulate feed intake in male and female rats [48]. The RFRP-3 neurons in the PVN are reported to give inputs to one-third of cells secreting $\mathrm{CRH}$ and oxytocin cells which can potentially impact feeding behavior and energy status in animals [83]. Talbi et al. [84] reported that the suppression of reproductive activity, weight gain, and hibernation in female desert jerboas is associated with higher RFRP-3 expression and found that ICV injection of RFRP-3 causes a 4-fold increase in food-intake female jerboas along with a decrease in POMC and increase in NPY expression levels. After this observation, he proposed a model to describe the regulation of energy balance and feeding by RFRP-3. According to his model, the projections of RFRP-3 exert a negative effect on anorexigenic POMC neurons and a positive effect on orexigenic NPY neurons to increase feed intake in female desert jerboas.

\section{Conclusions and Future Perspectives}

RFRP-3 is a pleiotropic neuropeptide that emerged as the regulator of the HPG axis and some critical reproductive events in mammals. It plays notable roles in stress-induced reproductive functions, sexual photoperiodism, and metabolic regulation. Localization, molecular characterization, mechanism of action, and pharmacological roles of RFRP-3 have been studied in several species during the past few decades. Due to the variability among species and sex, the precise role of RFRP-3 is yet to be determined. RRP-3 acts as a bridge between nutrition, stress, and reproduction and can be employed as therapeutic interventions in stress-induced infertility in mammals.

\section{Authors' Contributions}

DB: Conceived the idea. JM and SSM: Collected the literature and drafted the manuscript. PKD, PRG, and KD: Corrected the manuscript. All authors read and approved the final manuscript.

\section{Acknowledgments}

The authors are highly thankful to the honorable Vice-Chancellor, West Bengal University of Animal and Fishery Sciences, India, for providing facilities and necessary financial support (ICAR Development grant) to carry out this work. 


\section{Competing Interests} interests.

The authors declare that they have no competing

\section{Publisher's Note}

Veterinary World remains neutral with regard to jurisdictional claims in published institutional affiliation.

\section{References}

1. Xie, X., Liu, P., Chen, T., Wang, Y., Liu X., Ye, P., Wei, X. and Yan, Z. (2019) Influence of the hypothalamus-pituitary-gonadal axis reactivation and corresponding surging sex hormones on the amplitude of low-frequency oscillations in early pubertal girls: A resting state fMRI study. $J$. Affect. Disord., 256: 288-294.

2. Bonomi, M., Vezzoli, V. and Cariboni, A (2016) Control of GnRH secretion. In: Simoni, M. and Huhtaniemi I., editors. Endocrinology of the Testis and Male Reproduction. Springer, Cham.

3. King, J.C., Tobet, S.A., Snavely, E.L. and Arimura, A.A. (1982) LHRH immunopositive cells and their projections to the median eminence and organum vasculosum of the lamina terminalis. J. Comp. Neurol., 209(3): 287-300.

4. Ohlsson, B. (2017) Releasing hormone and its role in the enteric nervous system. Front. Endocrinol., 8: 110.

5. Angelopoulou, E., Quignon, C., Kriegsfeld, L.J. and Simonneaux, V. (2019) Functional implications of RFRP-3 in the central control of daily and seasonal rhythms in reproduction. Front. Endocrinol., 10: 183.

6. Leon, S. and Tena-Sempere, M. (2015) Dissecting the roles of gonadotropin inhibitory hormone in mammals: Studies using pharmacological tools and genetically modified mouse models. Front. Endocrinol., 6: 189.

7. Ogawa, S. and Parhar, I.S. (2018) Biological significance of kisspeptin-kiss 1 receptor signaling in the habenula of teleost species. Front. Endocrinol., 9: 222.

8. Hua, K.L., Changa, H.M., Lia, R., Yua, Y. and Qiao, J. (2019) Regulation of LH secretion by RFRP-3 from the hypothalamus to the pituitary. Front. Neuroendocrinol., 52: $12-21$.

9. Nejad, S.Z., Tehrani, F.R. and Zadeh-Vakili, A. (2017) The role of kisspeptin in female reproduction. Int. J. Endocrinol. Metab., 15(3): e44337.

10. Uenoyama, Y., Inoue, N., Nakamura, S. and Tsukamura, H. (2019) Central mechanism controlling pubertal onset in mammals: A triggering role of kisspeptin. Front. Endocrinol., 10: 312 .

11. Tng, E.L. (2015) Kisspeptin signalling and its roles in humans. Singapore Med. J., 56(12): 649-656.

12. Peraginea, D.E., Pokarowskia, M., Mendoza-Viveros, L., Swift-Gallanta, A., Chen, H.M. and Bentley, G.E. (2017) RFamide-related peptide-3 (RFRP-3) suppresses sexual maturation in a eusocial mammal. Proc. Natl. Acad. Sci. USA., 114(5): 1207-1212.

13. Trevisan, C.M., Montagna, E., de Oliveira, R., Christofolini, D.M., Barbosa, C.P., Crandall, K.A. and Bianco, B. (2018) Kisspeptin/GPR54 system: What do we know about its role in human reproduction? Cell. Physiol. Biochem., 49(4): 1259-1276.

14. Cao, Y., Li, Z., Jiang, W., Ling, Y. and Kuang, H. (2019) Reproductive functions of kisspeptin/KISS1R systems in the periphery. Reprod. Biol. Endocrinol., 17: 65.

15. Trujillo, M.V., Kalil, B., Ramaswamy, S. and Plant, T.M (2017) Estradiol upregulates kisspeptin expression in the preoptic area of both the male and female rhesus monkey (Macaca mulatta): Implications for the hypothalamic control of ovulation in highly evolved primates. Neuroendocrinology, 105(1): 77-89.
16. Hestiantoro, A., Astuti, B.P.K., Muharam, R., Pratama, G., Witjaksono, F. and Wiweko, B. (2019). Int. J. Endocrinol., 2019: Article Id: 1347208.

17. Tsutsui, K., Saigoh, E., Ukena, K., Teranishi, H., Fujisawa, Y., Kikuchi, M., Ishii, S. and Sharp, P.J. (2000) A novel avian hypothalamic peptide inhibiting gonadotropin release. Biochem. Biophys. Res. Commun., 275(2): 661-667.

18. Yin, H., Ukena, K., Ubuka, T. and Tsutsui, K. (2005) A novel G protein-coupled receptor for gonadotropin-inhibitory hormone in the Japanese quail (Coturnix japonica): Identification, expression and binding activity. $J$. Endocrinol., 184(1): 257-266.

19. Ducret, E., Anderson, G.M. and Herbison, A.E. (2009) RFamide-related peptide-3, a mammalian gonadotropin-inhibitory hormone ortholog, regulates gonadotropin-releasing hormone neuron firing in the mouse. Endocrinology, 150(6): 2799-2804.

20. Henningsen, J.B., Jens, C.A., Gauer, M.F. and Simonneaux, V. (2016) Roles of RFRP-3 in the daily and seasonal regulation of reproductive activity in female Syrian hamsters. Endocrinology, 3(1): 652-663.

21. Hinuma, S., Shintani, Y., Fukusumi, S., Iijima, N., Matsumoto, Y., Hosoya, M., Fujii, R., Watanabe, T., Kikuchi, K., Terao, Y., Yano, T., Yamamoto, T., Kawamata, Y., Habata, Y., Asada, M., Kitada, C., Kurokawa, T., Onda, H., Nishimura, O., Tanaka, M., Ibata, Y. and Fujino, M. (2000) New neuropeptides containing carboxy-terminal RFamide and their receptor in mammals. Nat. Cell Biol., 2(10): 703-708.

22. Ubuka, T., Morgan, K., Pawson, A.J., Osugi, T., Chowdhury, V.S., Minakata, H., Tsutsui, K., Millar, R.P. and Bentley, G.E. (2009b) Identification of human GnIH homologs, RFRP-1 and RFRP-3, and the cognate receptor, GPR147 in the human hypothalamic pituitary axis. PLoS One, 4(12): e8400.

23. Ubuka, T., Inoue, K., Fukuda, Y., Mizuno, T., Ukena, K., Kriegsfeld, L.J. and Tsutsui, K. (2012) Identification, expression, and physiological functions of Siberian hamster gonadotropin-inhibitory hormone. Endocrinology, 153(1): 373-385.

24. Ubuka, T., Lai, H., Kitani, M., Suzuuchi, A., Pham, V., Cadigan, P.A., Wang, A., Chowdhury, V.S., Tsutsui, K. and Bentley, G.E. (2009a) Gonadotropin-inhibitory hormone identification, cDNA cloning, and distribution in rhesus macaque brain. J. Comp. Neurol., 517(6): 841-855.

25. Talbi, R., Laran-Chich, M.P., Magoul, R., Ouezzani, S.E. and Simonneaux, V. (2016) Kisspeptin and RFRP-3 differentially regulate food intake and metabolic neuropeptides in the female desert jerboa. Sci. Rep., 6: Article Id: 36057.

26. Henningsen, J.B., Gauer, F. and Simonneaux, V. (2016) RFRP neurons the doorway to understanding seasonal reproduction in mammals. Front. Endocrinol. (Lausanne), 7: 36 .

27. Clarke, I.J., Sari, I.P., Qi, Y., Smith, J.T., Parkington, H.C., Ubuka, T., Iqbal, J., Li, Q., Tilbrook, A., Morgan, K., Pawson, A.J., Tsutsui, K., Millar, R.P. and Bentley, G.E. (2008) Potent action of RFamide-related peptide-3 on pituitary gonadotropes indicative of a hypophysiotropic role in the negative regulation of gonadotropin secretion. Endocrinology, 149(11): 5811-5821.

28. Ukena, K. and Tsutsui, K. (2005) A new member of the hypothalamic RF-amide peptide family, LPXRF-amide peptides: structure, localization, and function. Mass Spectrom. Rev., 24(4): 469-486.

29. Mamgain, A., Sawyer, I.L., David, A.M., Rizwan, T.M.Z., Evans, M.C., Ancel, C.M., Inglis, M.A. and Anderson, G.M. (2021) RFamide-related peptide neurons modulate reproductive function and stress responses. J. Neurosci., 41(3): 474-488.

30. Latif, R. and Rafique, N. (2015) Serum kisspeptin levels across different phases of the menstrual cycle and their correlation with serum oestradiol. Neth. J. Med., 73(4): $175-178$. 
31. Rizwan, M.Z., Porteous, R., Herbison, A.E. and Anderson, G.M. (2009) Cells expressing RFamide-related peptide-1/3, the mammalian gonadotropin-inhibitory hormone orthologs, are not hypophysiotropic neuroendocrine neurons in the rat. Endocrinology, 150(3): 1413-1420.

32. Kriegsfeld, L.J., Mei, D.F., Bentley, G.E., Ubuka, T., Mason, A.O., Inoue, K., Ukena, K., Tsutsui, K. and Silver, R. (2006) Identification and characterization of a gonadotropin inhibitory system in the brains of mammals. Proc. Natl. Acad. Sci. U. S. A., 103(7): 2410-2415.

33. Yano, T., Iijima, N., Kakihara, K., Hinuma, S., Tanaka, M. and Ibata, Y. (2003) Localization and neuronal response of RFamide related peptides in the rat central nervous system. Brain Res., 982(2): 156-167.

34. Johnson, M.A., Tsutsui, K. and Fraley, G.S. (2007) Rat RFamide-related peptide-3 stimulates GH secretion, inhibits LH secretion, and has variable effects on sex behaviour in the adult male rat. Horm. Behav., 51(1): 171-180.

35. Peragine, D.E., Pokarowski, M., Mendoza-Viveros, L., Swift-Gallant, A., Cheng, H.M., Bentley, G.E. and Holmes, M.M. (2017) RFamide-related peptide-3 (RFRP-3) suppresses sexual maturation in a eusocial mammal. Proc. Natl. Acad. Sci. U. S. A., 114(5): 1207-1212.

36. Thorson, J.F., Heidorn, N.L., Ryu, V., Czaja, K., Nonneman, D.J., Barb, C.R., Hausman, G.J., Rohrer, G.A., Prezotto, L.D., McCosh, R.B., Wright, E.C., White, B.R., Freking, B.A., Oliver, W.T., Hileman, S.M. and Lents, C.A. (2017) Relationship of neuropeptide FF receptors with pubertal maturation of gilts. Biol. Reprod., 96(3): 617-634.

37. Thorson, J.F., Prezotto, L.D., Cardoso, R.C., Sharpton, S.M., Edwards, J.F., Welsh Jr., T.H., Riggs, P.K., Caraty, A., Amstalden, M. and Williams, G.L. (2014) Hypothalamic distribution, adenohypophyseal receptor expression, and ligand functionality of RFamide-related peptide 3 in the mare during the breeding and nonbreeding seasons. Biol. Reprod., 90(2): 28.

38. Nguyen, T., Marusich, J., Li, J.X. and Zhang, Y. (2020) Neuropeptide FF and its receptors: Therapeutic applications and ligand development. J. Med. Chem., 63(21): 12387-12402.

39. Elshourbagy, N.A., Ames, R.S., Fitzgerald, L.R., Foley, J.J., Chambers, J.K., Szekeres, P.G., Evans, N.A., Schmidt, D.B., Buckley, P.T., Dytko, G.M., Murdock, P.R., Milligan, Graeme., Groarke D.A., Tan, K.B., Shabon, U., Nuthulaganti, P., Wang, D.Y., Wilson, S., Bergsma, D.J. and Sarau, H.M. (2000) Receptor for the pain modulatory neuropeptides $\mathrm{FF}$ and $\mathrm{AF}$ is an orphan $\mathrm{G}$ protein-coupled receptor. J. Biol. Chem., 275(34): 25965-25971.

40. Gouardères, C., Mazarguil, H., Mollereau, C., Chartrel, N., Leprince, J., Vaudry, H. and Zajac, J.M. (2007) Functional differences between NPFF1 and NPFF2 receptor coupling: High intrinsic activities of RFamide-related peptides on stimulation of [35S] GTP??S binding. Neuropharmacology, 52(2): 376-386.

41. Bentley, G.E., Ubuka, T., McGuire, N.L., Chowdhury, V.S., Morita, Y., Yano, T., Hasunuma, I., Binns, M., Wingfield, J.C. and Tsutsui, K. (2008) Gonadotropin-inhibitory hormone and its receptor in the avian reproductive system. Gen. Comp. Endocrinol., 156(1): 34-43.

42. Singh, P., Krishna, A., Sridaran, R. and Tsutsui, K. (2011) Immunohistochemical localization of GnRH and RFamiderelated peptide- 3 in the ovaries of mice during the estrous cycle. J. Mol. Histol., 42(5): 371-381.

43. Li, X., Su, J., Lei, Z., Zhao, Y., Jin, M., Fang, R., Zheng, L. and Jiao, Y. (2012) Gonadotropin-inhibitory hormone $(\mathrm{GnIH})$ and its receptor in the female pig: cDNA cloning, expression in tissues and expression pattern in the reproductive axis during the estrous cycle. Peptides, 36(2): 176-185.

44. Han, X., He, Y., Zeng, G., Wang, Y., Sun, W., Liu, J., Sun, Y. and Yu, J. (2017) Intracerebroventricular injection of RFRP-3 delays puberty onset and stimulates growth hormone secretion in female rats. Reprod. Biol. Endocrinol.,
15(1): 35 .

45. Poling, M.C., Luo, E.Y. and Kauffman, A.S. (2017) Sex differences in steroid receptor co-expression and circadian-timed activation of kisspeptin and RFRP-3 neurons may contribute to the sexually dimorphic basis of the LH surge. Endocrinology, 158(10): 3565-3578.

46. Xiang, W., Zhang, B., Lv, F., Ma, Y., Chen, H., Chen, L., Yang, F., Wang, P. and Chu, M. (2015) The inhibitory effects of RFamide-related peptide 3 on luteinizing hormone release involves an estradiol-dependent manner in prepubertal but not in adult female mice. Biol. Reprod., 93(2): 30 .

47. Wu, M., Dumalska, I., Morozova, E., van den Pol, A.N. and Alreja, M. (2009) Gonadotropin inhibitory hormone inhibits basal forebrain vGluT2-gonadotropin-releasing hormone neurons via a direct postsynaptic mechanism. J. Physiol., 587(Pt 7): 1401-1411.

48. Murakami, M., Matsuzaki, T., Iwasa, T., Yasui, T., Irahara, M., Osugi, T. and Tsutsui, K. (2008) Hypophysiotropic role of RFamide-related peptide-3 in the inhibition of LH secretion in female rats. J. Endocrinol., 199(1): 105-112.

49. Anderson, G.M., Relf, H.L., Rizwan, M.Z. and Evans, J.J. (2009) Central and peripheral effects of RFamide-related peptide- 3 on luteinizing hormone and prolactin secretion in rats. Endocrinology, 150(4): 1834-1840.

50. Henningsen, J.B., Ancel, C., Mikkelsen, J.D., Gauer, F. and Simonneaux, V. (2017) Roles of RFRP-3 in the daily and seasonal regulation of reproductive activity in female Syrian hamsters. Endocrinology, 158(3): 652-663.

51. Decourt, C., Anger, K., Robert, V., Lomet, D., BartzenSprauer, J., Caraty, A., Dufourny, L., Anderson, G. and Beltramo, M. (2016) No evidence that RFamide-related peptide 3 directly modulates LH secretion in the ewe. Endocrinology, 157(4): 1566-1575.

52. George, J.T., Hendrikse, M., Veldhuis, J.D., Clarke, I.J., Anderson, R.A. and Millar, R.P. (2017) Effect of gonadotropin-inhibitory hormone on luteinizing hormone secretion in humans. Clin. Endocrinol., 86(5): 731-738.

53. McGuire, N.L., Kangas, K. and Bentley, G.E. (2011) Effects of melatonin on peripheral reproductive function: Regulation of testicular $\mathrm{GnIH}$ and testosterone. Endocrinology, 152(9): 3461-3470.

54. Iwasa, T., Matsuzaki, T., Tungalagsuvd, A., Munkhzaya, M., Kuwahara, A., Yasui, T. and Irahara, M. (2015) Effects of LPS injection on the hypothalamic and testicular mRNA expression levels of reproductive factors in male rats. Neurol. Endocrinol. Lett., 36(3): 193-195.

55. Oishi, H., Klausen, C., Bentley, G.E., Osugi, T., Tsutsui, K., Gilks, C.B., Yano, T. and Leung, P.C.K. (2012) The human gonadotropin-inhibitory hormone ortholog RFamide related peptide-3 suppresses gonadotropin-induced progesterone production in human granulosa cells. Endocrinology, 153(7): 3435-3445.

56. Zhao, S., Zhu, E., Yang, C., Bentley, G.E., Tsutsui, K. and Kriegsfeld, L.J. (2010) RFamide related peptide and messenger ribonucleic acid expression in mammalian testis: Association with the spermatogenic cycle. Endocrinology, 151(2): 617-627.

57. Schneider, J.E., Benton, N.A., Russo, K.A., Klingerman, C.M., Williams, W.P. $3^{\text {rd }}$., Simberlund, J., Abdulhay, A., Brozek, J.M. and Kriegsfeld, L.J. (2017) RFamide-related peptide- 3 and the trade-off between reproductive and ingestive behavior. Integr. Comp. Biol., 57(6): 1225-1239.

58. Zmijewska, A., Czelejewska, W., Dziekonski, M., Gajewska, A., Franczak, A. and Okrasa, S. (2020) Effect of kisspeptin and RFamide-related peptide- 3 on the synthesis and secretion of LH by pituitary cells of pigs during the estrous cycle. Anim. Reprod. Sci., 214: Article Id: 106275.

59. McGuire, N.L. and Bentley, G.E. (2010) Neuropeptides in the gonads: From evolution to pharmacology. Front. Pharmacol., 1: 114.

60. Anjum, S., Krishna, A., Sridaran, R. and Tsutsui, K. (2012) 
Localization of gonadotropin-releasing hormone (GnRH), gonadotropin-inhibitory hormone $(\mathrm{GnIH})$, kisspeptin and GnRH receptor and their possible roles in testicular activities from birth to senescence in mice. J. Exp. Zool. A. Ecol. Genet. Physiol., 317(10): 630-644.

61. Malpaux, B., Migaud, M., Tricoire, H. and Chemineau, P. (2001) Biology of mammalian photoperiodism and the critical role of the pineal gland and melatonin. J. Biol. Rhythms, 16(4): 336-347.

62. Mao, C., Xu, Y., Shi, L., Guo, S., Jin, X., Yan, S. and Shi, B. (2019) Effects of photoperiod change on melatonin secretion, immune function and antioxidant status of cashmere goats. Animals (Basel), 9(10): 766.

63. Quignon, C., Beymer, M., Gauthier, K., Gauer, F. and Simonneaux, V. (2020) Thyroid hormone receptors are required for the melatonin-dependent control of Rfrp gene expression in mice. FASEB J., 34(9): 12072-12082.

64. Ubuka, T., Bentley, G.E., Ukena, K., Wingfield, J.C. and Tsutsui, K. (2005) Melatonin induces the expression of gonadotropin-inhibitory hormone in the avian brain. Proc. Natl. Acad. Sci. U. S. A., 102(8): 3052-3057.

65. Chowdhury, V.S., Tomonaga, S., Nishimura, S., Tabata, S., Cockrem, J.F., Tsutsui, K. and Furuse, M. (2012) Hypothalamic gonadotropin-inhibitory hormone precursor mRNA is increased during depressed food intake in heat-exposed chicks. Comp. Biochem. Physiol. A. Mol. Integr. Physiol., 162(3): 227-233.

66. Russo, K.A., La, J.L., Stephens, S.B.Z., Poling, M.C., Padgaonkar, N.A., Jennings, K.J., Piekarski, D.J., Kauffman, A.S. and Kriegsfeld, L.J. (2015) Circadian control of the female reproductive axis through gated responsiveness of the RFRP-3 system to VIP signaling. Endocrinology, 156(7): 2608-2618.

67. Simonneaux, V., Bahougne, T. and Angelopoulou, A. (2017) Daily rhythms count for female fertility. Pract. Res. Clin. Endocrinol. Metab., 31(5): 505-519.

68. Sun, W., Li, S., Tian, Z., Shi, Y., Yu, J., Sun, Y. and Wang, Y. (2019) Dynamic changes of RFRP3/GPR147 in the precocious puberty model female rats. Curr. Mol. Med., 19(10): 766-775.

69. Thorson, J.F., Desaulniers, A.T., Lee, C., White, B.R., Ford, J.J. and Lents, C.A. (2015) The role of RFamiderelated peptide 3 (RFRP3) in regulation of the neuroendocrine reproductive and growth axes of the boar. Anim. Reprod. Sci., 159: 60-65.

70. Lima, C., Cardoso, S.C., Lemos, E., Zingler, E., Capanema, C., Menezes, L.D., Vogado, G., Santos, B.D, de Moraes, O.L., Duarte, E.F., de Brito, V.N., Latronico, A.C. and Lofrano-Porto, A. (2014) Mutational analysis of the genes encoding RFamide-related peptide- 3 , the human orthologue of gonadotrophin-inhibitory hormone, and its receptor (GPR147) in patients with gonadotrophin-releasing hormone-dependent pubertal disorders. $J$. Neuroendocrinol., 26(11): 817-824.

71. Calisi, R.M., Rizzo, N.O. and Bentley, G.E. (2008) Seasonal differences in hypothalamic EGR-1 and GnIH expression following capture-handling stress in house sparrows (Passer domesticus). Gen. Comp. Endocrinol., 157(3): 283-287.

72. Ernst, D.K., Lynn, S.E. and Bentley, G.E. (2016) Differential response of $\mathrm{GnIH}$ in the brain and gonads following acute stress in a songbird. Gen. Comp. Endocrinol., 227: 51-57.

73. Jaroslawska, J., Chabowska-Kita, A., Kaczmarek, M.M. and Kozak, L.P. (2015) Npvf: Hypothalamic biomarker of ambient temperature independent of nutritional status. PLoS Genet., 11(6): e1005287.

74. Kaewwongse, M., Takayanagi, Y. and Onaka, T. (2011) Effects of RFamide-related peptide (RFRP)-1 and RFRP-3 on oxytocin release and anxiety-related behaviour in rats. $J$. Neuroendocrinol., 23(1): 20-27.

75. Kirby, E.D., Geraghty, A.C., Ubuka, T., Bentley, G.E. and Kaufer, D. (2009) Stress increases putative gonadotropin inhibitory hormone and decreases luteinizing hormone in male rats. Proc. Natl. Acad. Sci. USA., 106(27): 11324-11329.

76. McGuire, N.L., Koh, A. and Bentley, G.E. (2013) The direct response of the gonads to cues of stress in a temperate songbird species is season-dependent. PeerJ., 15,(1): e139.

77. Son, Y.L., Ubuka, T., Narihiro, M., Fukuda, Y., Hasunuma, I., Yamamoto, K., Belsham, D.D. and Tsutsui, K. (2014) Molecular basis for the activation of gonadotropin-inhibitory hormone gene transcription by corticosterone. Endocrinology, 155(5): 1817-1826.

78. Gojska, N.M. and Belsham, D.D. (2014) Glucocorticoid receptor-mediated regulation of Rfrp $(\mathrm{GnIH})$ and Gpr147 (GnIH-R) synthesis in immortalized hypothalamic neurons. Mol. Cell Endocrinol., 384(1-2): 23-31.

79. Geraghty, A.C., Muroy, S.E., Zhao, S., Bentley, G.E., Kriegsfeld, L.J. and Kaufer, D. (2015) Knockdown of hypothalamic RFRP3 prevents chronic stress-induced infertility and embryo resorption. Elife., 12(4): e04316.

80. Clarke, I.J., Smith, J.T., Henry, B.A., Oldfield, B.J., Stefanidis, A., Millar, R.P, Sari, I.P., Chng, K., FabreNys, C., Caraty, A., Ti Ang, B., Chan, L. and Fraley, G.S. (2012) Gonadotropin-inhibitory hormone is a hypothalamic peptide that provides a molecular switch between reproduction and feeding. Neuroendocrinology, 95(4): 305-316.

81. Anjum, S., Krishna, A. and Tsutsui, K. (2016) Possible role of $\mathrm{GnIH}$ as a mediator between adiposity and impaired testicular function. Front. Endocrinol. (Lausanne), 7: 1-12.

82. Morton, G.J., Cummings, D.E., Baskin, D.G., Barsh, G.S. and Schwartz, M.W. (2006) Central nervous system control of food intake and body weight. Nature, 443(7109): 289-295.

83. Amico, J.A., Vollmer, R.R., Cai, H.M., Miedlar, J.A. and Rinaman, L. (2005) Enhanced initial and sustained intake of sucrose solution in mice with an oxytocin gene deletion. $\mathrm{Am}$. J. Physiol. Regul. Integr. Comp. Physiol., 289(6): 798-806.

84. Talbi, R., Klosen, P., Laran-Chich, M.P., El Ouezzani, S. and Simonneaux, V. (2016) Coordinated seasonal regulation of metabolic and reproductive hypothalamic peptides in the desert jerboa. J. Comp. Neurol., 524(18): 3717-3728. 